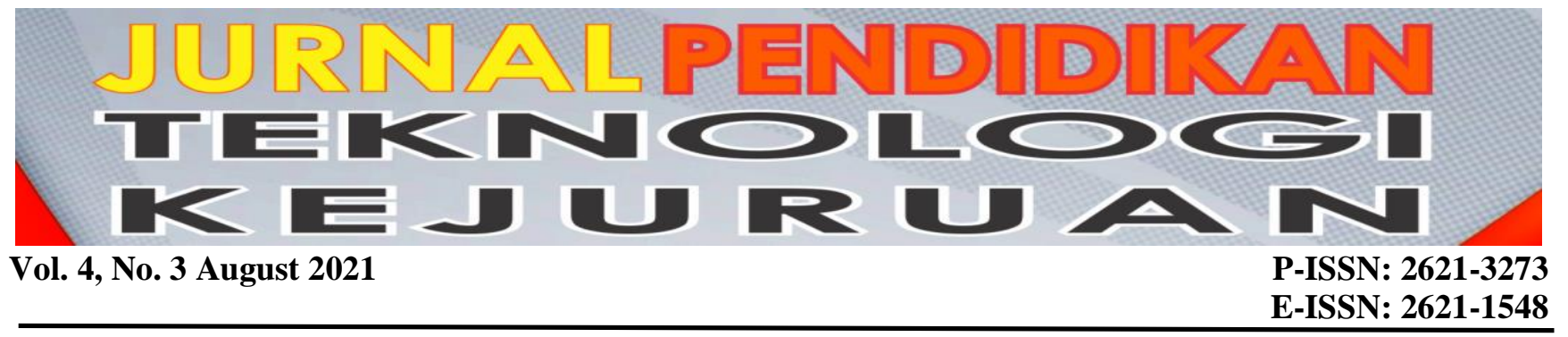

\title{
Evaluation Of Implementation of Learning Practices During Pandemicovid-19 Coating and Beauty Education Study Program
}

\author{
Erin Flowriza $^{1^{*}}$, Rahmiati $^{2}$ \\ ${ }^{1,2}$ Faculty of Tourism and Hospitality, Universitas Negeri Padang \\ "Corresponding author, e-mail: erinflowriza123@gmail.com
}

\begin{abstract}
Quantitative data analysis carried out included data descriptions and respondent's level of achievement in 4 (four) components, namely: context (context), input (input), product (process), output (result). Based on the results of the research that has been done, all incoming data meet the requirements for processing and analysis. Quantitative data were collected through a questionnaire consisting of 27 questions that had been tested for validity and reliability. Furthermore, the questionnaire was given to 104 students of the Faculty of Tourism and Hospitality in the Department of Makeup and Beauty in 2018 which were filled in online via google form to answer the questions given about the evaluation of the implementation of practical learning during the Covid-19 pandemic, the make-up and beauty study program. . statistical data of research evaluation of the implementation of practical learning during the Covid-19 pandemic, Makeup and Beauty Education Study Program. The table above shows that the number of data $(\mathrm{N})$ is 104 , mean 106.66 , median 107 , mode 109 , standard deviation 6.99 , variance 48.86 range 33 , minimum value 91, maximum value 124, and total Overall score of 11093. To complement the research data collected through questionnaires, the researcher also collected data by conducting interviews with several respondents, namely 4 lecturers of makeup and beauty at UNP. When conducting interviews, data were recorded and important points were recorded from the contents of the interview. Interview data were collected by researchers related to components in the evaluation of practical learning during the Covid-19 pandemic of make-up and beauty education study programs, namely components of context (context), input (input), process (process), and product (result).
\end{abstract}

Keywords: evaluation of the implementation of practical learning, make-up and beauty education

\section{INTRODUCTION}

Education is one of the keys to the formation of competent human resources in building the nation. Through education, it is expected to be able to create a generation that is useful for the nation and state as well as being able to compete in the international arena. Education is a supporting factor for a nation, so that it is used as a benchmark in the development and progress of the nation. Education has become a necessity to determine the direction of the future of humans, even the future of a nation. Education has a major role in personal and social development as well as individual and social influence. Without going through a good education process it will be difficult for someone to adapt to the developments and advances of the times. Therefore education is able to answer the challenges of modern life which are very necessary. The implementation of quality education is something that must be realized with various consistent and sustainable efforts.

In 2020, the global Covid-19 pandemic that hit the world or better known as the corona virus. The World Health Organization (WHO) has designated Covid-19 as a global pandemic (Cucinotta \& Vanelli, 2020). The development of the virus is spreading rapidly every day and data from all over the world are reporting the increasing spread and impact of Covid19. Corona Virus Disease 2019 or Covid-19 has infected millions of people in more than 200 countries around the world and caused many deaths (Khan et al., 2020). Indonesia is one of the countries affected by the spread of the Covid-19 virus and has been in a state of national emergency since the first finding of cases in March 2020. The Indonesian government established a non-natural disaster status for the Corona Covid-19 virus disease outbreak with the issuance of Presidential Decree (Keppres) No. 12 2020 concerning the Spread of Corona Virus Disease (Covid-19) as a National Disaster (Salkiah, B.2020). Some campuses implement policies for teaching and learning activities remotely or online lectures. Based on instructions from the Ministry of Education and Culture, Padang State University (UNP) issued the 
Chancellor's Circular Number: 1530/UN35/TU/2020 in preventing the spread of Covid-19. The increase in cases of the spread of Covid-19 in West Sumatra in the status of an Extraordinary Event (KLB) forced the UNP academic community to issue a policy based on the Chancellor's Circular Number 1593 / UN35 / AK / 2020 concerning campus activities in the context of Covid-19 pandemic alertness.

As of March 16, 2020, lectures at UNP will be held online / online. The June-December 2020 semester lectures are held using the http://elearning.unp.ac.id or other online platform until the end of the semester. The online platforms used are WhatApps, e-mail, Youtube and Zoom Cloud Meeting. Padang State University is one of the state universities that has a consistent focus on education and is able to produce other professional fields. One of the Education study programs at Padang State University is Makeup and Beauty Education which is an educational program that has the aim of producing a professional Bachelor of Education in the field of beauty.

The objectives of practical learning are 1) to improve students' practical ability to real conditions in the field, 2) add insight into information and train students' mindsets to be able to explore problems, then analyze and find solutions, 3) broaden students' general knowledge about the orientation of technology development in Indonesia. in the future, according to the theory given in class with the tasks faced in the field, 4) provide solutions to problems that exist during practice. The practical stages in the learning process, namely: 1) Delivery of goals to be achieved in the practical learning process, 2) Explanation of practical material, 3) Demonstration of correct work methods to students, 4) Exercise (Simulation Practice) to students as stated in the worksheet, and 5) Transfer exercise (Wena, 2016).

Practical learning courses at BP 2018 semester 5 of the July-December 2020 academic year that will be studied are Stage Makeup, Indonesian Bridal Makeup, Smoothing and Rebonding. Researchers chose this course because many students did not understand how to conduct online lectures during this pandemic. During the Covid-19 pandemic, online learning processes can be carried out. However, the implementation of online learning has an impact. This was conveyed by the Minister of Education and Culture Nadiem Makarim, there are three negative impacts, namely: 1) the threat of dropping out of school, 2) a decrease in learning achievement or material obtained by students, 3 ) increased stress by students.
The researcher conducted an interview with a lecturer in Makeup and Beauty Education who said that:

Table 1. Results of Interviews with Make-up and Beauty Lecturers

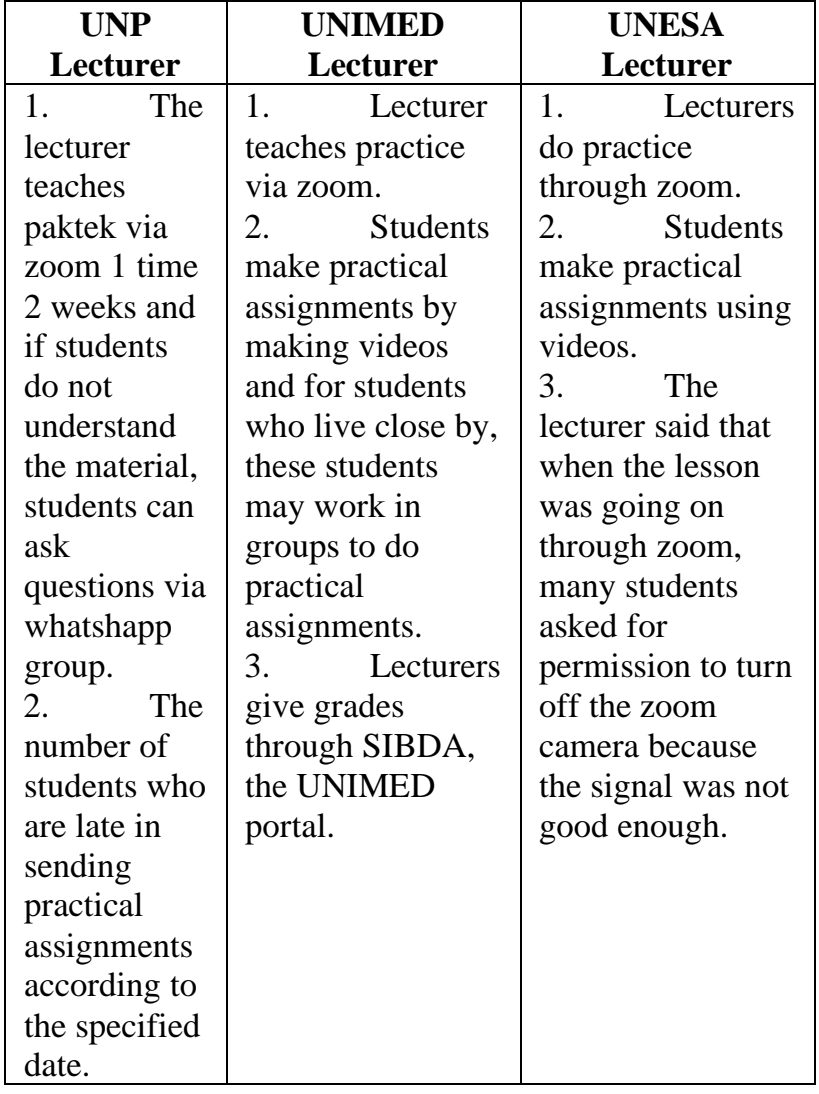

Based on the above constraints that cause problems for students, namely: e-learning media is considered ineffective in lectures, uneven internet signal quality, and lack of direction in a practice that will be carried out so that students do not understand. Of the 3 universities above, namely Padang State University, Medan State University and Surabaya State University, the problems that occur are deemed necessary to evaluate the implementation of online practical learning during the pandemic in revealing all the problems that exist in implementation.

This evaluation is expected to produce things that need to be addressed in the implementation of online practical learning. If a program is not evaluated, it cannot be known how far the policies issued have been implemented. As for students, the evaluation of online practical learning functions as a reaction that can improve competence and learning outcomes.

The researcher also conducted a pre-study to students of Makeup and Beauty BP 2018 UNP in the academic year July-December 2020. Observations were made to 10 students by distributing questionnaires to students, the results of which can be seen in the following table 2 . 
Table 2. Questionnaire Results for BP 2018 Makeup and Beauty Students

\begin{tabular}{|c|c|c|c|c|}
\hline No & Interview & $\begin{array}{c}\text { UNP } \\
\text { Respondents }\end{array}$ & $\begin{array}{c}\text { UNIMED } \\
\text { Respondents }\end{array}$ & $\begin{array}{c}\text { UNESA } \\
\text { Respondents }\end{array}$ \\
\hline 1 & $\begin{array}{l}\text { Students often } \\
\text { experience } \\
\text { server down } \\
\text { on e-learning }\end{array}$ & $50 \%$ & $60 \%$ & $70 \%$ \\
\hline 2 & $\begin{array}{l}\text { The difficulty } \\
\text { of sending } \\
\text { assignments } \\
\text { via e-learning }\end{array}$ & $50 \%$ & $50 \%$ & $40 \%$ \\
\hline 3 & $\begin{array}{l}\text { Unclear } \\
\text { delivery of } \\
\text { material via } \\
\text { WhatsApp } \\
\text { and zoom } \\
\text { meeting }\end{array}$ & $40 \%$ & $50 \%$ & $70 \%$ \\
\hline 4 & $\begin{array}{l}\text { Learning } \\
\text { environment } \\
\text { at home that is } \\
\text { less conducive } \\
\text { to learning }\end{array}$ & $40 \%$ & $40 \%$ & $40 \%$ \\
\hline 5 & $\begin{array}{l}\text { Fear of losing } \\
\text { your internet } \\
\text { signal during } \\
\text { college }\end{array}$ & $80 \%$ & $80 \%$ & $70 \%$ \\
\hline 6 & $\begin{array}{l}\text { Practices that } \\
\text { cannot be } \\
\text { done at home }\end{array}$ & $50 \%$ & $40 \%$ & $40 \%$ \\
\hline 7 & $\begin{array}{lr}\text { Absent } & \text { and } \\
\text { lack } & \text { of } \\
\text { materials } & \text { and } \\
\text { tools } & \text { for } \\
\text { practice } & \end{array}$ & $50 \%$ & $50 \%$ & $40 \%$ \\
\hline 8 & $\begin{array}{l}\text { Lackof } \\
\text { direction in a } \\
\text { practice that } \\
\text { will be carried } \\
\text { out so that } \\
\text { students do } \\
\text { not } \\
\text { understand }\end{array}$ & $70 \%$ & $60 \%$ & $60 \%$ \\
\hline
\end{tabular}

Based on the above constraints that cause problems for students, namely: e-learning media is considered ineffective in lectures, uneven internet signal quality, and lack of direction in a practice that will be carried out so that students do not understand. Evaluation of the implementation of online-based practice learning during a pandemic has never been evaluated before. This needs to be done because program evaluation is a systematic process to collect, analyze and use information in answering basic questions related to a program (Wirawan, 2011:17). Where the purpose of the program evaluation is to see the extent to which online practice learning during the pandemic has been carried out and the obstacles encountered during the implementation of learning. One of the program evaluation models that can be used is the Context, Input, Process, and Product (CIPP) model. The CIPP model is a suitable model to use in this evaluation because it has the main goal of improving a program.
As described previously, there are four components in the CIPP model, namely Context (aspects of the needs and problems of UNP Makeup and Beauty students), Input (aspects of educators, students and facilities and infrastructure from UNP makeup and beauty students), process (implementation aspects, suitability and barriers of UNP make-up and beauty students), Product (aspects of the effects produced by UNP make-up and beauty students).

Most evaluators use the CIPP model because this model is more comprehensive than other models. This evaluation model was developed by Daniel Stuffleabem, et al (1967) at Ohio State University which was originally used to evaluate ESEA (the Elementary and Secondary Education Art). As previously explained, CIPP has four components which represent each abbreviation of CIPP where the four components are an activity program that is applied in the evaluation of this model. In this case, it can be seen that the CIPP model views the program being evaluated as a system. Through this research, it is expected to be able to answer the problems that occur in the learning of Makeup and Beauty Education Practices at Padang State University.

Based on the background of the problems above, there are a number of problems that can be identified. Here is a description of the problem.

1. The need for implementing online practical learning during the pandemic has not been met.

2. Learning facilities that do not support the implementation of online practical learning.

3. Limited internet signal in accessing learning during the pandemic.

Based on the identification of the problem, the problem can be formulated as follows:

1. How is the context of implementing online practical learning at UNP in terms of goals, planning and needs?

2. How to input the suitability and readiness of teaching staff in the implementation of online practical learning at UNP in terms of educators, students, and infrastructure and costs?

3. How is the process of implementing online practical learning at UNP in terms of implementation, suitability, obstacles and solutions?

4. How Products implement online practical learning at UNP in terms of the impact and influence it produces?

\section{A. Learning and Learning}

Learning is a complex process that occurs in a person throughout his life with one of the signs, namely a 
change in behavior (Azhar, 2019:1). Mayer 1982 also argues that learning is concerned with relatively permanent behavioral changes in one's knowledge or behavior due to experience. Meanwhile, Bell-Gredler argues that learning is a process carried out to obtain a variety of abilities (competencies), skills (skills), and attitudes that are obtained gradually and continuously (in Karwono and Mularsih 2018:13).

Azhar's opinion focuses that learning is a process of changing behavior. Then Mayer emphasizes that learning is a relatively permanent change in behavior. Meanwhile, Bell-Gredler states that learning is to gain competencies, skills, and attitudes. From the explanation above, it can be concluded that learning is a change in the level of behavior that is assessed by a person's competencies, skills and attitude.

Based on the expert's opinion, it is concluded that learning is an activity that is planned by external factors (teachers) so that the formation of a learning process from individuals (students) according to student needs and student interests. There are many things that affect the learning process which are grouped into internal and external factors.

\section{B. Learning Makeup and Beauty}

The Makeup and Beauty Education study program is organized to produce prospective teachers and instructors in the field of beauty. Students who graduate from the Makeup and Beauty Education Study Program are entitled to a Bachelor of Education (S.Pd.). This study program is expected to be able to prepare professional and expert human resources in the field of Makeup and Beauty.

The learning objectives of Make-Up and Beauty Education are to provide students with knowledge of theoretical concepts in the field of Makeup and Beauty Education and to be able to apply educational knowledge and solve problems faced in the field in the expertise of Makeup and Beauty. The learning experiences provided include theoretical lectures in class, practicum activities in the laboratory, educational internships or Guided Field Practices (PLT), industrial practices, and Real Work Lectures (KKN).

\section{Practical Learning}

Practical learning is a process to improve the skills of students by using various methods in accordance with the skills provided and the equipment used. Practice is an effort to provide opportunities for participants to gain direct experience. Experience encourages students to reflect or look back at the experiences they have experienced (Wiguna et al, 2016). The basic idea of experiential learning encourages trainees to reflect or look back on the experiences they have had.

\section{Online Learning}

The term online learning or online learning is a synonym for the same. It's just that online is a term in Indonesian, and online is a term in English. According to the Big Indonesian Dictionary (KBBI), online is defined as an abbreviation of being in a network or connected through computer networks, the internet, and so on (Kemendikbud, 2020). Online learning is defined as the use of the internet to access material, interact with instructors and other learners, to get support during the learning process (Ally, 2004). According to Trisnadewi and Muliana, (2020: 40), online learning is an interaction between teachers and learners that is built in a network through a computer or other electronic device. Online learning according to Adriyanto et al (2020) is learning in which teaching materials are sent digitally in an internet (online) network to students in different locations where students become learning centers and demand independent learning.

Based on the understanding of online learning, it can be interpreted as an interaction that occurs between students and teachers in the learning process that is connected to the internet network through electronic devices and online platforms that provide a learning experience. The learning process that occurs provides independent learning in obtaining information obtained from online documents and databases, online exercises, online assignments, searching for individual learning materials, sharing knowledge online with other students, video conferencing, and interactive discussions (Anggrawan, 2019). During the Covid-19 pandemic, online learning became a solution to unravel the mass activities that caused the crowd to unravel the spread of Covid-19 (Pragholapati, 2020).

\section{E. Program Evaluation}

Program evaluation is a systematic stage used to analyze, collect, and use information to answer basic questions related to the program (Wirawan, 2011). According to Ralph Tyler quoted by Sudaryono, which states that program evaluation is a process to find out whether educational goals can be realized (Sudaryono, 2014). Furthermore, according to Cronbach (1963) and Stufflebeam (1971) quoted by (Suharsimi, 2009), program evaluation is an effort to provide information to be conveyed to decision makers. Another opinion states that program evaluation is an effort to obtain information about a program produced to assess the extent to which these activities have been carried out in accordance with the 
initial planning and then used as a reference for making further decisions (Ambiyar, 2019).

From the above opinion it can be concluded that evaluation is an activity to collect information which is then used to determine the right alternative in making a decision whether to continue, improve or stop, formulate policies or as a consideration in making decisions for the benefit of making further programs.

\section{F. Covid-19 Pandemic}

COVID-19 (Coronavirus Disease 2019). Covid-19 is a virus that attacks human respiration. Coronavirus is a family of viruses that causes diseases ranging from mild to severe symptoms, the type of coronavirus is known to cause diseases that can cause severe symptoms such as Middle East Respiratory Syndrome (MERS) and Severe Acute Respiratory Syndrome (SARS) ) (Health, 2020).

According to (Ministry of Home Affairs, 2020), several things must be done in preventing this virus, namely doing hand hygiene using hand sanitizer if hands don't look dirty or washing hands with soap if hands look dirty, avoiding touching eyes, nose and mouth, applying cough etiquette. or sneezing by covering the nose and mouth with the inner upper arm or tissue, then throwing the tissue in the trash, wearing a medical mask if you have respiratory symptoms and doing hand hygiene after throwing out the mask, keeping a distance (at least $1 \mathrm{~m}$ ) from people who experience symptoms of the disorder respiration (Ministry, 2020).

The impact of Covid-19 has caused the economy in Indonesia to decline, the rupiah exchange rate dropped, the price of goods rose, especially medical devices. This also had an impact on the education system in Indonesia. The decision from the education minister stated that all learning activities were good in schools and colleges implemented in their respective homes through the available application. The Minister of Education issued Circular Letter Number 3 of 2020 concerning Prevention of Corona Virus Disease (Covid-19) to the Education Unit which stated that schools and universities were closed. (MoEC, 2020).

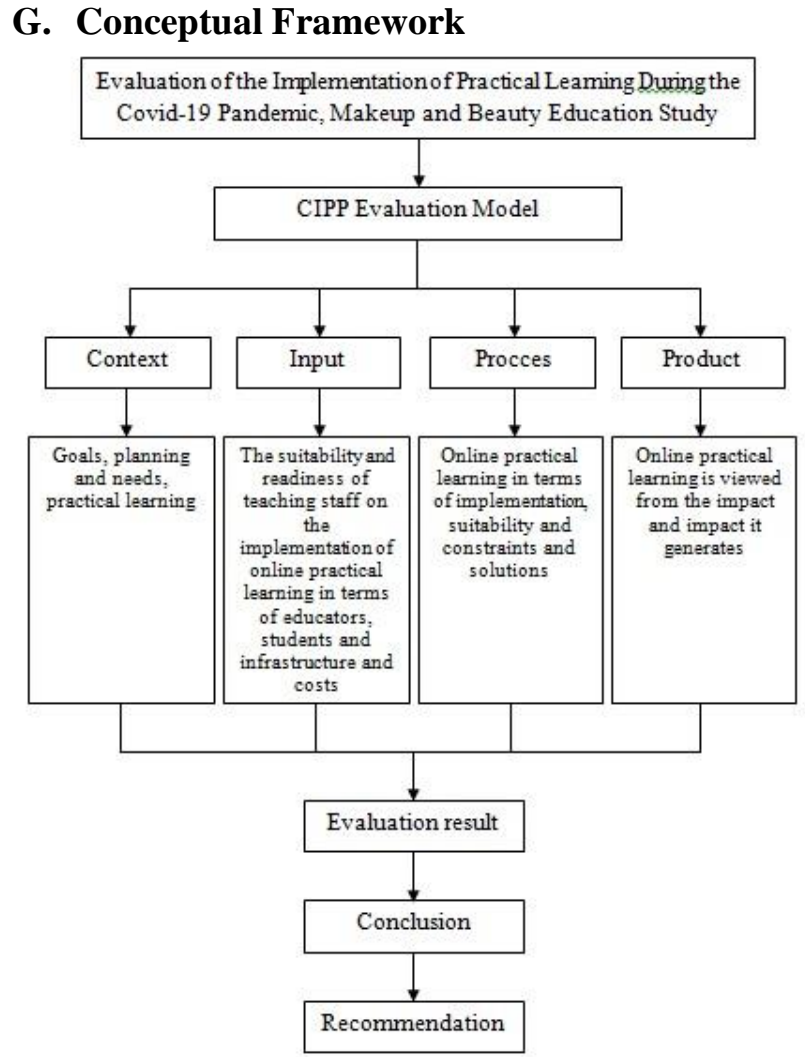

Figure 1. Framework

\section{METHOD}

The research method used is a combination method (Mixed Method) with quantitative and qualitative approaches in order of evidence (sequential explanatory). The quantitative approach in this study uses statistical processing numbers and qualitative approaches to reveal phenomena that occur and are lifted from the facts fairly, not from controlled or manipulated conditions. In strengthening the description of quantitative data, qualitative data is used which is obtained from the results of documentation, interviews, and observations to research subjects.

The type of research used is evaluation (Evaluation Research) with the Context, Input, Process, Product (CIPP) model which aims to determine the end of a program in order to determine recommendations for past policies and so on with the aim of improvement (Suharsimi and Cepi, 2014 ). In this case, the researchers evaluated the implementation of the UNP Beauty and Makeup Education practical learning implementation during the Covid-19 pandemic which was reviewed from (a) Context, (b) Input, (c) Process, and (d) Product.

The place for the evaluation of practical learning implementation research is at Padang State University in the UNP Makeup and Beauty Education Study Program which will be held in January 2021. The evaluation research respondents for the quantitative approach are 5th semester students who 
are taking Compulsory Courses (Practice Learning) Study Programs UNP Makeup and Beauty Education which has implemented practical learning during the Covid-19 pandemic for one semester. Respondents for the qualitative research were the teaching staff of the Compulsory Course for the Makeup and Beauty Education Study Program at UNP who had implemented practical learning during the Covid-19 pandemic for one semester. The respondents involved in evaluation research are as shown in the table 3.

Table 3. Respondents involved

\begin{tabular}{|l|l|c|c|}
\hline No & \multicolumn{1}{|c|}{ Respondents } & Amount & Approach \\
\hline 1. & 2018 Student & 104 Person & Quantitative \\
\hline 2. & Teaching Staff & 4 Person & Quantitative \\
\hline
\end{tabular}

\section{RESULT}

\section{Context Component}

Context components in the implementation of practical learning during the Covid-19 pandemic, make-up and beauty education study programs are divided into 3 indicators / sub indicators in terms of objectives, planning and needs. Based on the questionnaire given to 104 students with 27 questions, the results for the objective indicator were 3.90 with an achievement level of $78.07 \%$ and included in the sufficient category. This means that in the implementation of practical learning during the covid-19 pandemic, the cosmetology and beauty education study program has a big goal of increasing student knowledge and optimizing the teaching and learning process.

The results of interviews regarding the objectives of implementing practical learning during the covid-19 pandemic of make-up and beauty education study programs in practical learning during the Covid 19 pandemic through zoom, WhatsApp and e-learning did not improve the ability of female students to practice because when doing practical learning, students were often constrained by network and lack of tools and practice materials when doing practice. The results for planning indicators obtained an average of 3.88 with a presentation rate of $77.19 \%$ and included in the sufficient category. This means that the implementation of practical learning during the covid-19 pandemic of make-up and beauty education study programs has a fairly good plan.

The average score of the context indicators for the implementation of practical learning during the Covid-19 pandemic of make-up and beauty education study program was obtained by 4.01 with an achievement level of $80.02 \%$ and included in the good category. It can be concluded that the context component needs to be optimized for the indicators of objectives, planning and needs. The table below shows the combined results of quantitative and qualitative data analysis carried out on the context component.

Table 4. Combined results of quantitative and qualitative

\begin{tabular}{|l|l|l|}
\hline \multicolumn{1}{|c|}{ Context } & Quantitative & \multicolumn{1}{c|}{ Qualitative } \\
\hline implementati & implementati & implementati \\
on of & on of & on of \\
practical & practical & practical \\
learning & learning & learning \\
during the & during the & during the \\
covid-19 & covid-19 & covid-19 \\
pandemic, & pandemic, & pandemic, \\
the make-up & the & the \\
and beauty & cosmetology & cosmetology \\
education & and beauty & and beauty \\
study & education & education \\
program was & study & study \\
categorized & program & program on \\
as good with & showed good & the indicators \\
a total TPR & results that & of goals, \\
of 80.02\% & supported & planning and \\
& quantitative & needs is \\
data. & categorized \\
& & as sufficient. \\
\hline
\end{tabular}

Based on the explanation above, it can be concluded that the implementation of practical learning during the Covid-19 pandemic education study program on make-up and beauty in a quantitative and dermal context is already in a good category.

The results of the interview regarding the planning of giving assignments in the form of videos to female students overwhelmed the students because of the many obstacles experienced by students, one of which was that the female students did not understand enough in making videos. The results for the need indicator obtained an average of 4.16 with a presentation rate of $83.20 \%$ and included in the good category. This means that the implementation of practical learning during the covid-19 pandemic, the cosmetology and beauty education study program has a lot of needs.

The results of interviews regarding the need for implementing practical learning during the covid-19 pandemic of the cosmetology and beauty education study program can be concluded that the lecturer's need for internet access while on campus. Because lecturers need a stable signal when teaching practice via zoom. 


\section{Input Components}

The input component in the implementation of practical learning during the covid-19 pandemic of make-up and beauty education study programs is divided into four indicators / sub indicators in terms of educators, students, facilities and infrastructure and costs. Based on the questionnaire given to 104 students with 27 questions, the results for the educator indicator were 3.87 with an achievement level of $77.40 \%$ and included in the sufficient category. This means that the implementation of practical learning during the covid-19 pandemic, the cosmetology and beauty education study program has good educators who meet the criteria of a lecturer.

The results of interviews with educators can be concluded that the results of practical learning preparation during the Covid-19 pandemic by lecturers are in accordance with existing material. This means that lecturers are professional in teaching because they follow procedures in teaching. The results for the indicator of learners (students) obtained an average of 3.99 with a presentation level of $79.80 \%$ and included in the enough category. This means that the implementation of practical learning during the Covid-19 pandemic for make-up and beauty education study programs has been understood by most students of the make-up and beauty education study program.

The results of interviews about students (students) can be concluded that the problems faced by students in implementing practice in the UNP cosmetology and beauty education study program are unstable networks, incomplete tools and materials and difficulty in finding models for practice. The results for the facilities and infrastructure indicators obtained an average of 3.86 with a presentation rate of $77.31 \%$ and included in the sufficient category. This means that the implementation of practical learning during the Covid-19 pandemic for make-up and beauty education study programs has been supported by sufficient facilities and infrastructure.

The average acquisition score of the input indicators for the implementation of practical learning during the covid-19 pandemic of the cosmetology and beauty education study program was obtained at 3.90 with an achievement rate of $78.08 \%$ and was included in the sufficient category. The table below shows the combined results of the quantitative and qualitative data analysis carried out on the input components.
Table 5. combined results of the quantitative and qualitative data

\begin{tabular}{|l|l|l|}
\hline \multicolumn{1}{|c|}{ Input } & Quantitative & Qualitative \\
\hline implementati & implementati & implementati \\
on of & on of & on of \\
practical & practical & practical \\
learning & learning & learning \\
during the & during the & during the \\
covid-19 & Covid-19 & Covid-19 \\
pandemic, & pandemic, & pandemic for \\
the make-up & the make-up & make-up and \\
and beauty & and beauty & beauty \\
education & education & education \\
study & study & study \\
program was & program & programs \\
categorized & showed good & pada \\
as sufficient & results cukup & indikator \\
with the total & which & educators, \\
TPR 78,08\% & supports & students, \\
& quantitative & facilities and \\
& data. & infrastructure \\
& & and costs are \\
& & categorized \\
& & as sufficient. \\
\hline
\end{tabular}

Based on the explanation above, it can be concluded that the implementation of practical learning during the Covid-19 pandemic of make-up and beauty education study programs on quantitative and qualitative data are categorized as sufficient.

The results of interviews regarding facilities and infrastructure can be concluded that the implementation of practical learning during the covid-19 pandemic of make-up and beauty education study program is the lack of readiness of facilities and infrastructure for students at home in the practice of make-up and beauty study programs during the covid19 pandemic.

The results for the cost indicator obtained an average of 3.89 with a presentation level of $77.78 \%$ and included in the sufficient category. This means that the implementation of practical learning during the Covid-19 pandemic for make-up and beauty education study programs has been supported by minimal costs. The results of interviews regarding costs can be concluded that the implementation of practical learning during the covid-19 pandemic of the cosmetology and beauty education study program is very minimal because the costs are borne by students.

\section{DISCUSSION}

The implementation of practical learning during the covid-19 pandemic, the cosmetology and beauty education study program is divided into two indicators/sub-indicators which are viewed from the impact and influence. Based on the questionnaire 
given to 104 students with 27 questions, the results for the impact indicator were 3.91 with an achievement level of $78.27 \%$ and included in the sufficient category. This means that the results of the implementation of practical learning during the COVID-19 pandemic, the cosmetology and beauty education study program are quite good.

The results of the interview regarding the impact can be concluded that in the implementation of practical learning during the covid-19 pandemic, the cosmetology and beauty education study program is dissatisfaction as a lecturer because they cannot observe directly and directly correct mistakes that occur during practice. The results for the influence indicator obtained an average of 3.91 with a presentation level of $78.17 \%$ and included in the sufficient category. This means that the implementation of practical learning during the covid-19 pandemic, the cosmetology and beauty education study program has an unfavorable influence on learning during the covid-19 pandemic. The results of the interview regarding the effect can be concluded that the implementation of practical learning during the Covid-19 pandemic of make-up and beauty education study programs, many female students do not understand practical material so that many students have poor grades.

The average score obtained from the result indicator (product) of implementing practical learning during the covid-19 pandemic, the cosmetology and beauty education study program was obtained at 3.91 with an achievement rate of $78.22 \%$ and was included in the sufficient category. It can be concluded that the result component has met the implementation of practical learning during the covid-19 pandemic, the cosmetology and beauty education study program, but there are still several indicators that need to be optimized in order to get good results.

Table 6. Combined results of quantitative and qualitative data analysis carried out on the product components.

\begin{tabular}{|l|l|l|}
\hline \multicolumn{1}{|c|}{ Product } & Quantitative & \multicolumn{1}{c|}{ Qualitative } \\
\hline $\begin{array}{l}\text { implementation } \\
\text { of practical }\end{array}$ & implementati & the \\
on of & implementati \\
the covid-19 & practical & on of \\
pandemic, the & learning & practical \\
dosmetology and & Covid-19 & learning \\
beauty education & pandemic, the & covid-19 \\
study program is & make-up and & pandemic, the \\
categorized as & beauty & cosmetology \\
sufficient with a & education & and beauty \\
total TPR of & study & education \\
$78.17 \%$ & program & study \\
& showed quite & program on \\
\hline
\end{tabular}

\begin{tabular}{|l|l|l|}
\hline & $\begin{array}{l}\text { good results } \\
\text { that support } \\
\text { quantitative } \\
\text { data. }\end{array}$ & $\begin{array}{l}\text { impact and } \\
\text { influence } \\
\text { indicators is } \\
\text { categorized as } \\
\text { sufficient. }\end{array}$ \\
\hline
\end{tabular}

Based on the explanation above, it can be concluded that the implementation of practical learning during the Covid-19 pandemic education study program on make-up and beauty in the product components is in the quite good category. Product components that have been evaluated and obtained good results need to be improved and optimized for each component element.

\section{CONCLUSION}

1. The context component has a sufficient predicate with an average TPR of $79.72 \%$ where this result is supported by qualitative data which strengthens the basis of the results of quantitative data processing. The context component that is classified as sufficient needs to be improved and the context component that is sufficient needs to be improved again in its implementation in practical learning during the covid-19 pandemic of the cosmetology and beauty education study program.

2. The input component of implementing practical learning during the covid-19 pandemic in the cosmetology and beauty education study program is sufficient with a TPR of 78.08 which is strengthened by qualitative data which assesses that this input component is categorized as adequate, but improvements need to be made so that the results obtained can be well, where the results of this quantitative data analysis are in accordance with qualitative data which states input on the implementation of practical learning during the Covid-19 pandemic of make-up and beauty education study programs in terms of educators, students, facilities and infrastructure as well as funding for practical implementation.

3. The components of the implementation process of practical learning during the covid-19 pandemic in the cosmetology and beauty education study program are categorized as quite good with a TPR of 80.47 because there are still a few problems faced by students and teachers that have not been fully resolved. This proves that this process component needs to be improved in the future so that the implementation of practical learning during the covid-19 pandemic in the cosmetology and beauty education study program has excellent results, where this result is in line with qualitative data analysis that the implementation of the teaching and 
learning process is good and the curriculum is run in accordance with government demands. However, it still has obstacles in its implementation, namely in overcoming student boredom in practicing at home.

4. The process of implementing practical learning during the Covid-19 pandemic in the make-up and beauty education study program in terms of results is classified as good with TPR 80.60 where students or students have unsatisfactory knowledge and skills in their field.

\section{REFERENCES}

Adriyanto, A. R., Santosa, I., \& Syarief, A. 2020.Evaluasi Heuristik Sistem Pengelolaan Pembelajaran Daring Perguruan Tinggi Di Indonesia.Andharupa: Jurnal Desain Komunikasi Visual \& Multimedia, 6(02), 215234.

Ally, M. 2004. Foundations of Educational Theory for Online Learning. In Theory and Practice of Online Learning (pp. 15-44).

Anggrawan, A. (2019). Analisis Deskriptif Hasil Belajar Pembelajaran Tatap Muka dan Pembelajaran Online Menurut Gaya Belajar Mahasiswa. MATRIK: Jurnal Manajemen, Teknik Informatika Dan Rekayasa Komputer, 18(2), 339-346.

Arsyad, Azhar. 2019. MediaPembelajaran. Depok: Rajawali Pers.

Darsono, H., Fitri, A. N., Rahardjo, B., Imanuela, M. Z., \& Lasambouw, C. M. 2020.Efektivitas Pembelajaran Jarak Jauh saat Pandemi Covid19 (Kajian di Politeknik Negeri Bandung).In Prosiding Industrial Research Workshop and National Seminar. 11(1), 1235-1240.

Daryanto.2013. Strategi Tahapan Mengajar dan Bekal Keterampilan Dasar bagi Guru.Bandung: CV Yrama Widya.

Endang, Mulyatiningsih. 2011. Metode Penelitian Terapan Bidang Pendidikan. Bandung: Alfabeta

Fuadi, T. M., Musriandi, R., \& Suryani, L. 2020. Covid-19: Penerapan Pembelajaran Daring Di Perguruan Tinggi. Jurnal Dedikasi Pendidikan, 4(2), 193-200.
Khan, B., H. .1997. Web Based Instruction, Educational Technology Publications. New Jersey: Englewood Cliffs,

Karwono,\& Heni Mularsih. 2018. Belajar dan Pembelajaran. Depok: Rajawali Pers.

Kustandi, Cecep \& Sutjipto, Bambang. 2011. Media Pembelajaran. Bogor: Gahlia Indonesia.

Kemdikbud, R.2020. Edaran Tentang Pencegahan Wabah COVID-19 di Lingkungan Satuan Pendidikan Seluruh Indonesia.

Mutrofin. 2010. Evaluasi Program, Teks Pilihan Untuk Pemula. Yogyakarta: Lakesbang Pressindo.

Paryanto, P. 2008. Evaluasi Pelaksanaan Praktik Pemesinan Mahasiswa D3 Teknik Mesin UNY. Jurnal Pendidikan Teknologi dan Kejuruan, 17(1), 99-118.

Pragholapati, A. 2020. Covid-19 Impact On Students. Review Article.

Reece, I. \& Walker, S. 1997. Teaching, Training, and Learning.Sunderland: Arthenaeum Press.

Silahuddin, S. 2015. Penerapan E-Learning dalam Inovasi Pendidikan. CIRCUIT: Jurnal Ilmiah Pendidikan Teknik Elektro, 1(1), 48-59.

Sofyan H. 2015. Metodelogi Pembelajaran Kejuruan. Yogyakarta: UNY Press.

Sudjana Djuju. 2008. Evaluasi Program Pendidikan Luar Sekolah. Bandung: Rosdakarya

Sugiyono. 2014. Metode Penelitian Kuantitatif, Kualitatif Dan $R \& D$. Bandung: Alfabeta.

Sugiyono. 2015. Cara Mudah Menyusun Skripsi, Tesis, dan Disertasi. Bandung: Alfabeta.

Suharsimi A \& Cepi, S, A, J. 2014.Evaluasi Program Pendidikan, Pedoman Praktis Bagi, Mahasiswa dan Praktisi Pendidikan. Jakarta: Bumi Aksara.

Suharsimi Arikunto. 2018. Dasar-Dasar Evaluasi Pendidikan. Jakarta: Bumi Aksara

Sukardi. 2014. Evaluasi Program Pendidikan dan Kepelatihan. Jakarta: PT. Bumi Aksara. 
Sukmadinata. 2006. Landasan Psikologi Proses. Bandung: Rosda

Stufflebeam, D.L. 1972. Education Evaluation and Decision Making, F.E. peacock publishers inc. Itasca, illionis.

Stufflebeam, D.L. dan shinkfield, A.J. 2007.Evaluation Theory, Models And Applications. San Fransisco, CA: Jossey-bass.

Trisnadewi, K., \& Muliani, N. M. 2020.Pembelajaran Daring di Masa Pandemi Covid-19. COVID19: Perspektif Pendidikan 